ISSN 0206-5657. Вісник Львівського університету. Серія біологічна. 2018 Випуск 78. С. 8-13 Visnyk of the Lviv University. Series Biology. 2018. Issue 78. P. 8-13

\title{
RESTORATION AND CONSERVATION OF HISTORICAL COLLECTIONS DAMAGED BY WATER IN HERBARIUM KL
}

\author{
S. Kuss, D. Vogt, R. Eberwein \\ Regional Museum of Carinthia, Carinthian Botanic Center \\ 1, Prof.-Dr.-Kahler-Platz, Klagenfurt am Wörthersee 9020, Austria \\ e-mail: roland.eberwein@landesmuseum.ktn.gv.at
}

The burst of a water pipe affected several historical collections of the Carinthian Herbarium [KL] some decades ago. Fascicles were kept close and they were not dried by suitable heating equipment. As a result, many herbarium sheets became completely clotted and severely damaged by mould. At first, in 2009 we started to restore the famous 'Traunfellner collection'. About 14000 exsiccatae collected between 1805 and 1835 were cleaned, restored, and specimens were mounted on archival paper. Remains of extremely damaged specimens were peeled off by means of Japanese tissue paper and archival glue (inversely fixed), and also mounted. This new method enabled access to the whole collection again. The restoration of historical collections of algae is still ongoing.

Keywords: historical herbarium, water damage, restoration of herbarium sheets, mould on herbarium, algae collection

\section{Introduction}

Herbaria are very important collections documenting not only biodiversity [7] but also many aspects of history of science, ethnology, and biographies. The Carinthian Herbarium [KL] is a mid-sized herbarium comprising about 240000 specimens, with its oldest collections dating back to 1752 . Several decades ago, some old and important collections were damaged by water. For lack of anything better, the affected fascicles (folders) were left where they were. As a result, many fascicles contained completely clotted sheets severely infested by mould (Figs 1, 4). The fascicles were transferred into a new building in 1998, where they still remained untreated. In a first step, we separated different collections and in 2009 started to restore the herbarium of Alois Traunfellner (1782-1840), a pharmacist from Klagenfurt (Austria), containing mainly phanerogams and comprising about 14000 exsiccatae collected by various botanists between 1805 and 1835. Since 2017, the historical collections of algae are undergoing restoration and updating.

\section{Material and methods}

The whole work cycle in restoring mouldy and clotted herbarium sheets consists of cleaning of the fascicles, opening clotted envelopes and sheets, cleaning of the specimens, peeling off the sticking plant remains and their transfer to Japanese tissue paper, and reconstruction of the specimen, mounting on archival paper and returning into the restored original envelopes.

Envelopes were cleaned manually with a soft brush [6], followed by disinfection with $70 \%$ ethanol [1-2, 4-6]. Damaged paper was fixed with a self-adhesive technical Japanese tissue paper (filmoplast ${ }^{\circledR}$ R; Neschen) applied by means of a special heating element (Coverite ${ }^{\text {TM }} 21^{\text {st }}$ Century iron) or an iron. For inverse fixation of plant remains, a special Japanese tissue paper (Kizuki-Ko$\mathrm{zu}$; Japico Vienna) was used. Methyl-cellulose (Methylan normal; Henkel) turned out to be the best solution for inverse fixation and wheat starch for mounting specimens and labels [3]. Museums cardboard of archival quality (Hahnemühle, $300 \mathrm{~g} / \mathrm{m}^{2}$ ) was used as herbarium paper.

\section{Results}

Before starting with restoration work, a viability test of mould spores was made. In spite of annual gas treatment of the herbarium KL with phosphane $\left(\mathrm{PH}_{3}\right)$ for many years, spores of mould

(C) Kuss S., Vogt D., Eberwein R., 2018 
fungi turned out to be viable. For cleaning procedures, an escape and arrangements for respiratory protection should be used.

Opening clotted envelopes and/or fascicles (folders) has to be done with extreme caution because any mechanical treatment increases damage. Best results could be obtained by moist treatment using ethanol and/or steam. Plant remains are scattered on both sides of paper in most cases (Fig. 2). Large parts of specimens of phanerogams can be removed from moist paper with scalpel and tweezers, rearranged and, depending on their size, fixed with starch on Japanese tissue paper or with paper stripes on museums cardboard. Crumbly remains of plants need a special treatment. We covered crumbles sticking on the envelope with Japanese tissue paper and saturated it with Methyl-cellulose glue. Glue causes sticking of crumbles on the Japanese tissue paper whereas the water of the glue softens the envelope. After a short time span which has to be tested, the crumbles sticking on Japanese tissue paper can be peeled off (Fig. 3), flattened, and air-dried. The plant remains are kept in this inversely fixed stage and they are mounted together with the Japanese tissue paper on museums cardboard, or enclosed by a capsule.

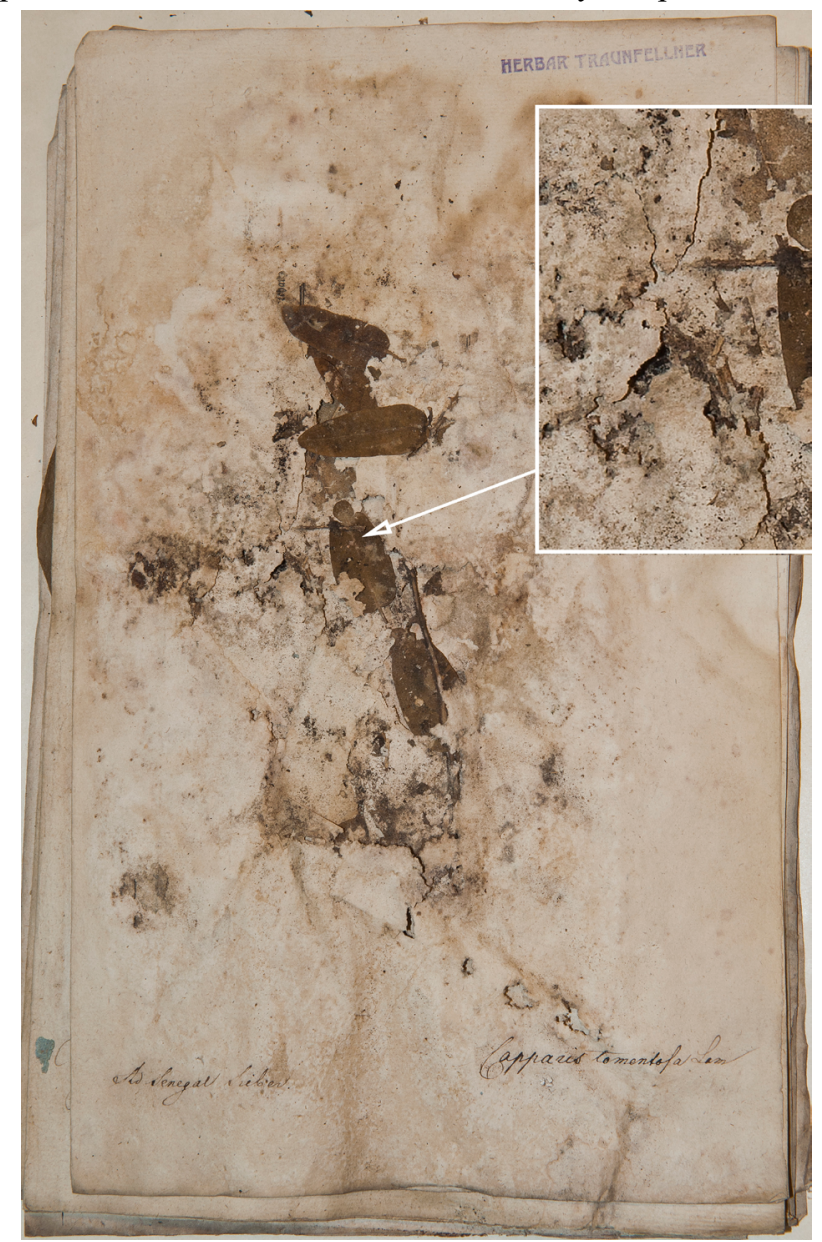

Fig. 1. Severely damaged herbarium sheet of Capparis tomentosa Lam. collected by Franz Wilhelm Sieber in Senegal. Plant remains are infested by the same mould as the paper which is broken (insert) due to decomposing fungi 


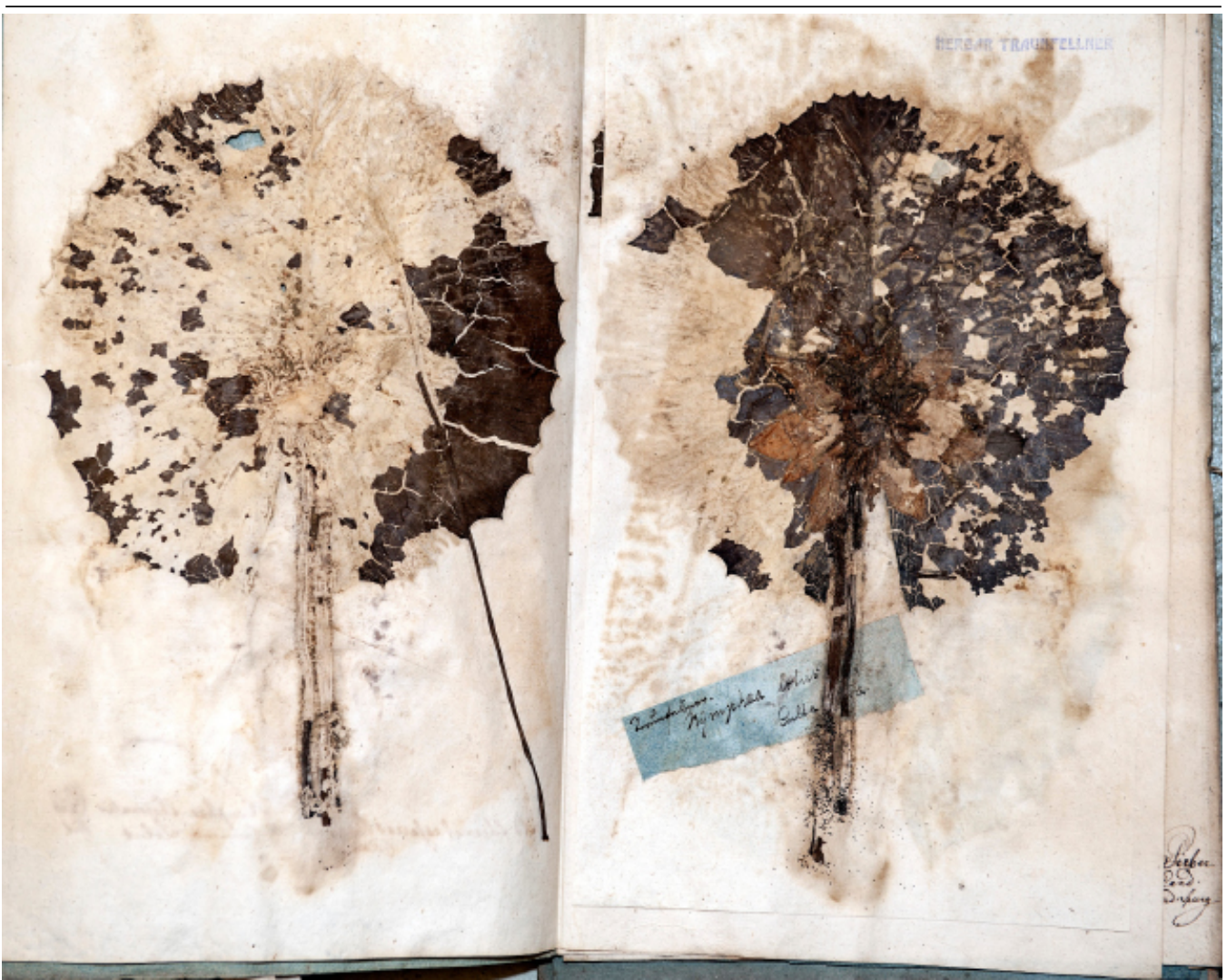

Fig. 2. A leaf of a cultivated Nymphaea lotus L. after opening the paper envelope. Remains of the leaf are sticking on both sides of the paper

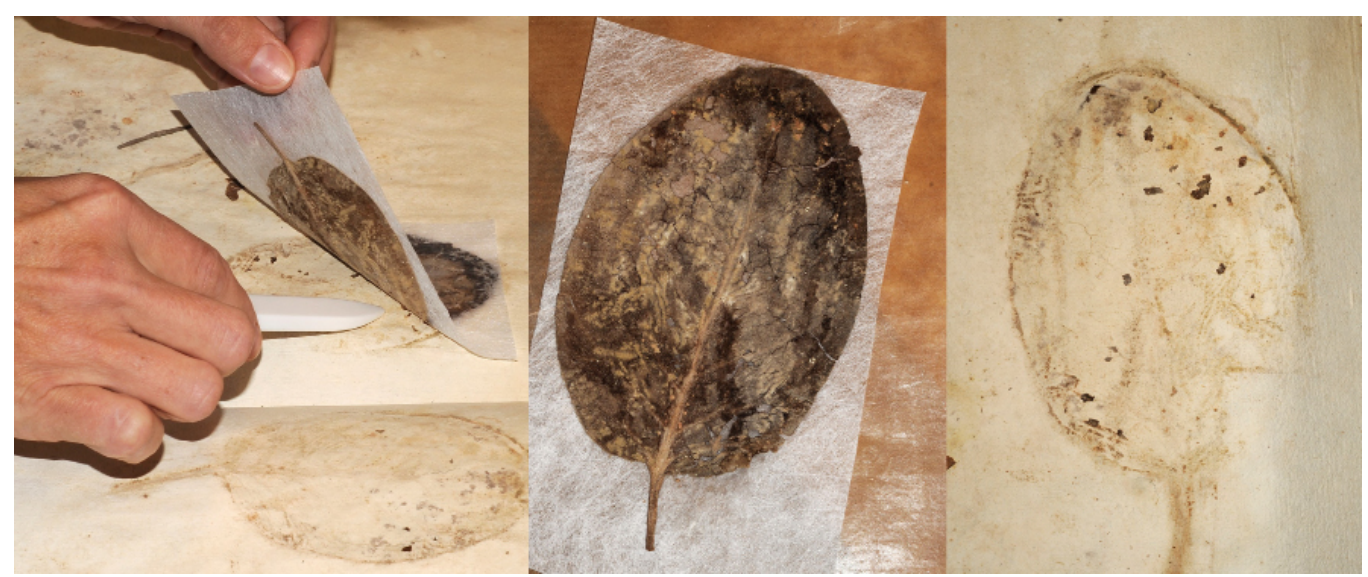

Fig. 3. Inverse fixation. Japanese tissue paper is glued on the surface of leaf remains. Wet glue allows peeling off the leaf remains from the historical paper without damage (left). Leaf remains become inversely fixed on Japanese tissue paper (middle) and can be mounted with the Japanese tissue paper on a new herbarium sheet. The more or less clean original envelope (left) is restored separately and used as an envelope again 
Restoration of algal collections is much more difficult, and its results are often unsatisfactory (Fig. 4). Especially the opening of clotted envelopes has to be done with extreme care. Lack of tissue and vessels, as well as the presence of sticky polysaccharides, hinders inverse fixation. Parts of algae remain on both sides of the enclosing paper and cannot be removed. Both sides of paper should be prepared and stored as one specimen (Fig. 5).

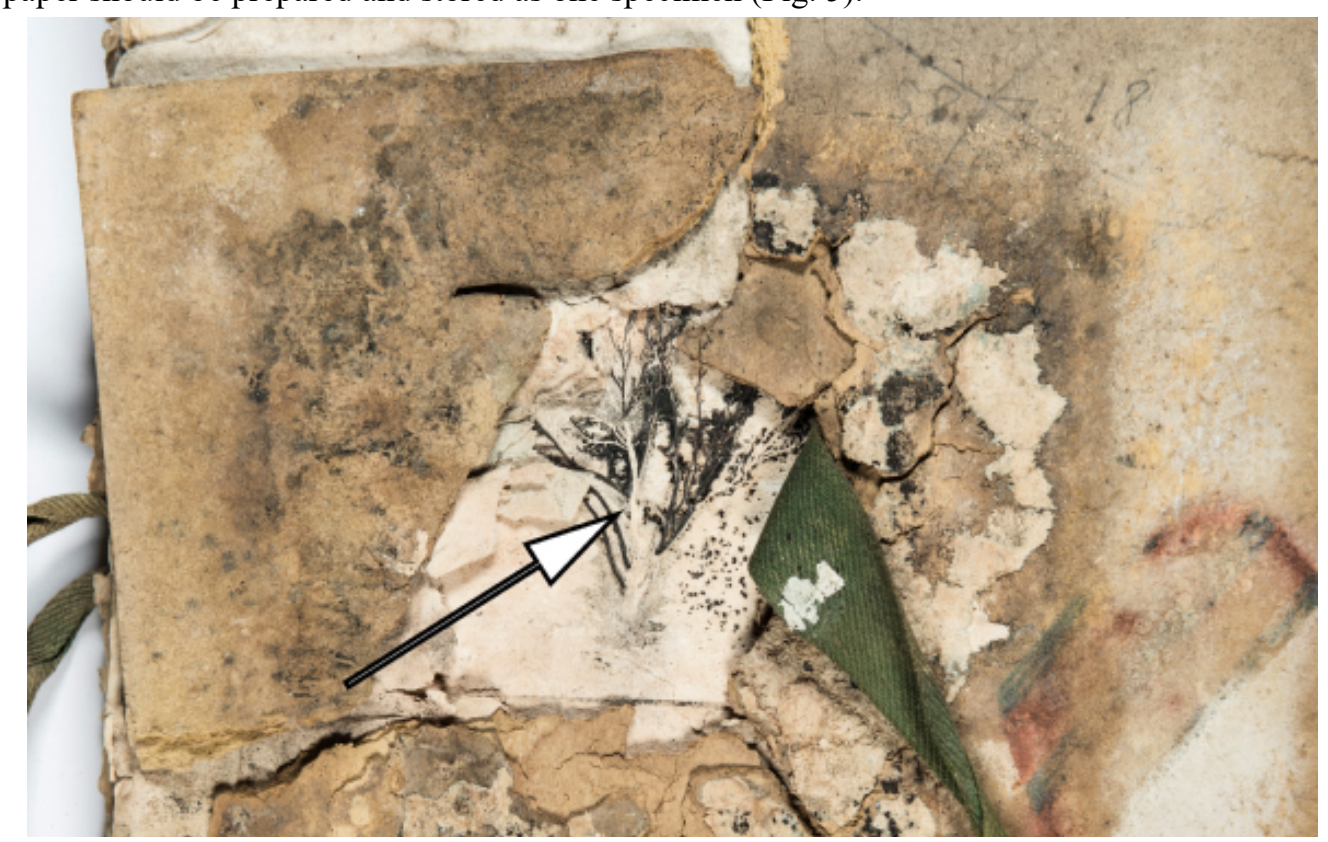

Fig. 4. Fascicle of the historical collection of algae of Karl Leveling. The arrow points to mouldy remains of an alga. The fascicle cardboard is partly decomposed

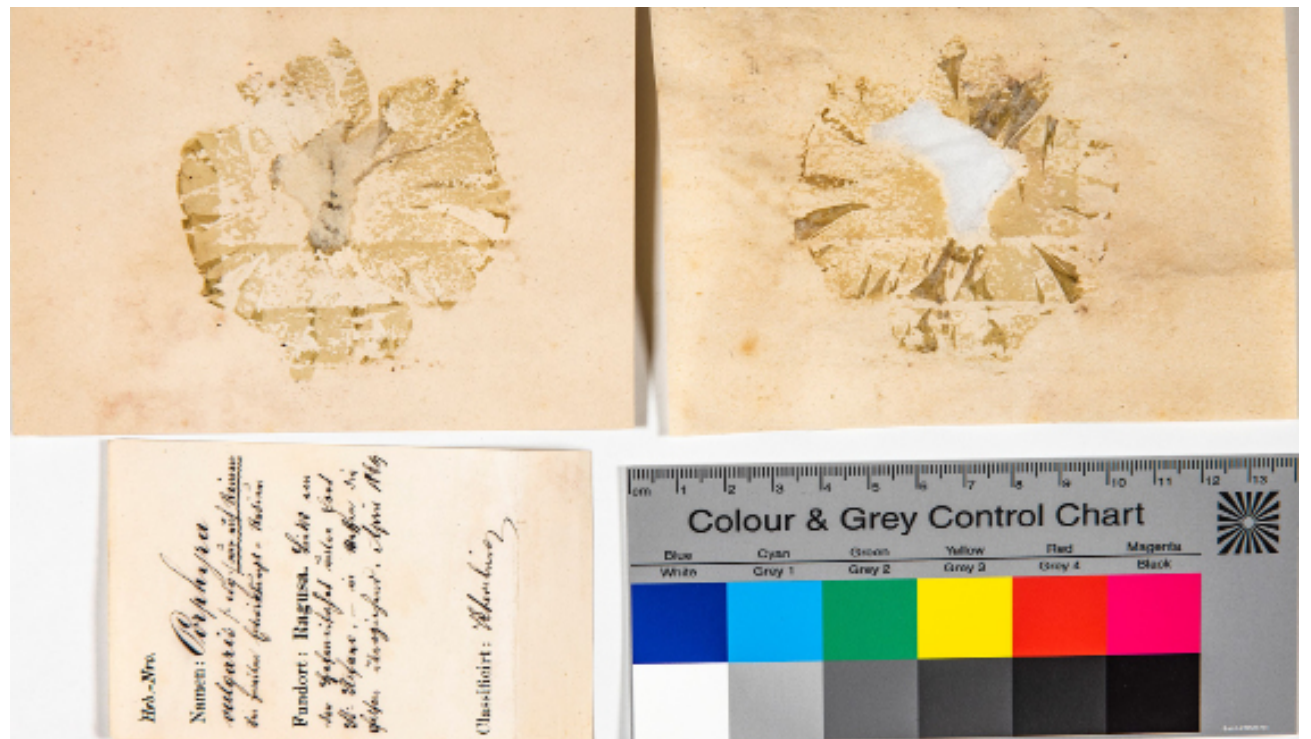

Fig. 5. Restored specimen and label of the red alga Porphyra vulgaris C. Agardh (= P. purpurea C. Agardh) collected 1869 in Ragusa (Dubrovnik, Croatia) 


\section{Conclusion}

Restoration of water-damaged herbarium collections is a difficult task and it should be done by experienced staff after training in paper restoration. It is necessary to carry out the whole process within the herbarium to prevent further damage and loss of material, and to accompany restoration procedures by botanists and curators. Parts of envelopes and papers with notes may not be disposed and the context of envelopes, specimens and labels has to be preserved. Original labels should never be replaced by newly produced ones. Transcriptions, emendations, completions and supplements have to be added to the herbarium sheet and marked with an exact date. Even if an exsiccate is completely destroyed, label data should be stored on so-called 'dummy sheets' documenting the fact, that this particular exsiccate is destroyed.

\section{Acknowledgements}

Special thanks goes to the herbarium manager of KL, H. Koll; to the collaborators C. Brückler, A. Knoltsch, J. Mößlacher, and K. Schüttenkopf; to H. Riegler-Hager for mycological examinations, and to the paper-restorer of the Austrian National Library, I. Mühlbacher, for technical advice. The work was funded by the Austrian Federal Ministry for Education, Arts and Culture (project № GZ 38.000/0016-IV/4/2009) and the Austrian Federal Chancellery (project № BKA-K208.722/0001-II/7/2016 and BKA-K208.722/0001-II/7/2017).

\section{REFERENCES}

1. Förster A., Kreuzberg A.-N. Schimmelpilzbefallenes Kunst und Kulturgut. Ein Erfahrungsbericht zu Entschimmelungen // Restauro. 2010. Vol. 6. P. 370-379.

2. Hödl I. Mikroorganismen auf Papier: Prophylaktische Konservierung, Identifizierung, Desinfektion und Restaurierung // Preprints. 1995. P.181-193.

3. Kuß S., Eberwein R.K. Instandsetzung verschimmelter Pflanzenbelege aus dem Herbarium Traunfellner mittels inverser Fixierung auf Japanpapier // Carinthia II. 2013. Vol. 203/123. N. 2. P.507-514.

4. Meier C. Schimmelpilze auf Papier. Fungizide Wirkung von Isopropanol und Ethanol // Papier Restaurierung. 2006. Vol.7. N.1. P.22-29.

5. Meier C., Petersen K. Schimmelpilze auf Papier. Ein Handbuch für Restauratoren. Biologische Grundlagen, Erkennung, Behandlung und Prävention. K.: Der Andere Verlag: Lübeck, Marburg, 2006. 188 p.

6. Moroz R. Reinigung von Papier, Pappe, Kartons, Leder und Pergament. In: Handbuch der Oberflächenreinigung; Eipper, P.-B. Ed.; Dr. C. Müller-Straten: München, 2011. P. 214-227.

7. Stuessy T.F., Sohmer S. H. Sampling the green world. Innovative concepts of collection, preservation and storage of plant diversity. K.: Columbia University Press: New York, 1996. 287 p. 


\title{
ВІДНОВЛЕННЯ І ЗБЕРЕЖЕННЯ ІСТОРИЧНИХ КОЛЕКЦІЙ, ПОШКОДЖЕНИХ ВОДОЮ В ГЕРБАРІЇ КL
}

\author{
С. Кусс, Д. Фогт, Р. Ебервайн \\ Регіональний музей Каринтії, Каринтійський ботанічний центр \\ Проф.-д-р-Калер-Плати, 1, Клагенфурт-на-Вюртерзее 9020, Австрія \\ e-mail:roland.eberwein@landesmuseum.ktn.gv.at
}

Гербарії- це дуже важливі колекції, які документують не лише біорізноманіття, але також багато аспектів історії науки, етнології та життєписів. Каринтійський гербарій $[\mathrm{KL}]$ - це гербарій середнього розміру, що містить близько 240000 екземплярів, із найстарішими колекціями, які датуються 1752 роком.

Кілька десятиліть тому вода із прорваної труби пошкодила низку історичних колекцій Каринтійського гербарію. Гербарні аркуші зі зразками були спаковані досить тісно, тому належно не просушились. Унаслідок цього багато гербарних аркушів повністю „зсілись“ і сильно пошкодилися цвіллю. У 2009 р. ми почали відновлювати знамениту колекцію Alois Traunfellner (1782-1840). Близько 14000 ексикатів, зібраних між 1805 і 1835 роками, було очищено, відновлено і змонтовано на архівному папері. Залишки сильно пошкоджених зразків знімали за допомогою японського паперу й архівного клею (обернена фіксація) і також монтували. Відновлення колекцій водоростей було набагато складнішим і не таким успішним. Зокрема, відкриття склеєних конвертів слід було виконувати 3 особливою обережністю. Відсутність тканин і судин, а також утворення липких полісахаридів перешкоджають оберненій фіксації. Частини водоростей залишаються на обох боках паперу та не можуть бути вилучені. Обидва боки паперу мають бути збережені як один зразок.

Відновлення пошкоджених водою колекцій гербарію - це важке завдання, яке має здійснювати досвідчений персонал після відповідного тренування. Весь процес має відбуватися під наглядом ботаніків і кураторів у приміщенні гербарію, щоб запобігти подальшому пошкодженню і втраті матеріалу. Частини конвертів і паперів з нотатками не можна викидати, тому що вміст конвертів, зразків і етикеток має бути збережений. Оригінальні етикетки ніколи не слід замінювати новими. Транскрипції, виправлення та доповнення мають бути додані до аркуша гербарію і позначені точною датою. Навіть якщо ексикат був повністю знищений, дані заміток слід зберігати на так званих фіктивних аркушах, документуючи факт, що цей конкретний ексикат було втрачено.

Цей новий метод дав змогу знову отримати доступ до всієї колекції.

Ключові слова: Каринтія, гербарій, пошкодження, метод, відновлення 